\title{
Mass changes of alpine glaciers at the eastern margin of the Northern and Southern Patagonian Icefields between 2000 and 2012
}

\author{
DANIEL FALASCHI, ${ }^{1}$ TOBIAS BOLCH, $^{2}$ PHILIPP RASTNER, $^{2}$ \\ MARÍA GABRIELA LENZANO, ${ }^{1}$ LUIS LENZANO, ${ }^{1}$ ANDRÉS LO VECCHIO, ${ }^{1}$ \\ SILVANA MORAGUES ${ }^{1}$ \\ ${ }^{1}$ Instituto Argentino de Nivología, Glaciología y Ciencias Ambientales (IANIGLA), CCT-Mendoza, \\ C. C. 330 Mendoza, Argentina \\ ${ }^{2}$ Department of Geography, University of Zurich, Winterthurerstrasse 190, Switzerland \\ Correspondence: Daniel Falaschi <dfalaschi@mendoza-conicet.gov.ar>
}

\begin{abstract}
Despite renewed efforts to better understand glacier change and recognize glacier change trends in the Andes, relatively large areas in the Andes of Argentina and Chile are still not investigated. In this study, we report on glacier elevation and mass changes in the outer region of the Northern and Southern Patagonian Icefields in the Southern Patagonian Andes. A newly-compiled Landsat ETM+ derived glacier inventory (consisting of 2253 glaciers and $\sim 1314 \pm 66 \mathrm{~km}^{2}$ of ice area) and differencing of the SRTM and SPOT5 DEMs were used to derive glacier-specific elevation changes over the 2000-12 period. The investigated glaciers showed a volume change of $-0.71 \pm 0.55 \mathrm{~km}^{3} \mathrm{a}^{-1}$, yielding a surface lowering of $0.52 \pm 0.35 \mathrm{~m} \mathrm{a}^{-1}$ on average and an overall mass loss of $0.46 \pm 0.37 \mathrm{~m}$ w.e. $\mathrm{a}^{-1}$. Highly variable individual glacier responses were observed and interestingly, they were less negative than previously reported for the neighboring Patagonian Icefields.
\end{abstract}

KEYWORDS: glacier mass balance, glacier volume, mountain glaciers

\section{INTRODUCTION}

In a nearly global context of glacier shrinkage in response to climate change, many glaciers are losing ice volume through increased melt, hence contributing to sea-level rise (Hock and others, 2009; Jacob and others, 2012; Gardner and others, 2013). The large glaciers and ice masses in the Southern Patagonian Andes are no exception (Rignot and others, 2003; Rivera and others, 2005, 2007; Chen and others, 2007; Ivins and others, 2011). Both the Northern and Southern Patagonian Icefields (hereafter NPI and SPI, respectively) and their outlet glaciers, which have been acknowledged as the largest temperate ice masses in the southern hemisphere (Warren and Sugden, 1993), have shown high thinning rates since the second half of the 20th century (Rignot and others, 2003; Willis and others, 2012a, b).

Since the 1940s in-situ glacier mass-balance measurements have been carried out on glaciers of various sizes in many glacierized regions worldwide using the traditional glaciological method (Zemp and others, 2015). The WGMS 2013 Glacier Mass-Balance Bulletin dataset contains 37 glaciers for which $30+$ observation years are available (WGMS, 2013). The in-situ measurement of glacier mass balance is highly valuable for understanding the processes related to Earth-atmosphere mass and energy fluxes. It is nevertheless a time-consuming and laborious task, and thus cannot be conducted for a large number of glaciers. Moreover, the mass balance of a given glacier may be largely affected by particular topo-climatic factors (glacier size, slope and aspect, wind direction, among others) and consequently, the direct extrapolation of mass-balance measurements to a larger scale must be approached with care (Gardner and others, 2013).

In approximately the last decade, geodetic studies utilizing remotely-sensed data have complemented the in-situ mass-balance surveys, which allow for making wider-scale assessments on glacier changes (e.g. Bolch and others, 2011; Nuimura and others, 2012; Gardelle and others, 2013; Kääb and others, 2015 in the Himalaya; Pieczonka and Bolch, 2015 in the Tien Shan, 2013 Fischer and others, 2015 in the Alps or Berthier and others, 2010 in Alaska). Though temporally limited by the availability of good quality DEMs, the geodetic mass-balance method provides a more comprehensive and broader overview on the glaciers' state and evolution in comparison with in-situ measurements. Additionally, the geodetic method enables the validation and calibration of mass-balance determinations carried out by means of the glaciological method (Zemp and others, 2013), and is useful to understand the controls of observed glacier changes (e.g. Abermann and others, 2011; Carturan and others, 2013; Fischer and others, 2015).

By comparing glacier surface topography over different years and making density assumptions to convert ice volume to mass change, the geodetic mass-balance method has become increasingly utilized to derive glacier mass changes. Moreover, co-registration tools have significantly increased the accuracy of this method based on multi-source DEMs, (e.g. Berthier and others, 2007; Bolch and others, 2008a; Koblet and others, 2010; Lenzano, 2013; Rastner and others, 2016).

The Southern Andes of Chile and Argentina extend for more than $3000 \mathrm{~km}$ and host an estimated $>29000 \mathrm{~km}^{2}$ of 
glacier area (Pfeffer and others, 2014). In recent decades, increasingly available satellite imagery has allowed for a better understanding of the current state of glaciers in Patagonia (e.g. Aniya, 1988, 1999, 2001; Aniya and others, 1997; Davies and Glasser, 2012; Bown and others, 2014; Sakakibara and Sugiyama, 2014). Commonly, these studies have mainly focused on glacier area changes, and have shown sustained and widespread glacier wastage (e.g. Schneider and others, 2007; Falaschi and others, 2013; Masiokas and others, 2015), and glacier area decline rates of up to $\sim 1 \% \mathrm{a}^{-1}$ (see e.g. Paul and Mölg, 2014). For the Monte San Lorenzo region, which is encompassed within the study area here, Falaschi and others (2013) estimated an ice-covered area of $\sim 207 \mathrm{~km}^{2}$ in 2008 and a reduction of $0.8 \% \mathrm{a}^{-1}$ between 1985 and 2008 .

Glacier length and area changes represent, however, a delayed response to climate change and are affected by debris cover, whereas glacier mass balance is a more direct and immediate response, and offers a more direct assessment of glacier health (Bhattachayra and others, 2016). Yet, in the Southern Patagonian Andes and in terms of glacier mass changes, only the Patagonian Icefields (NPI, SPI and Gran Campo Nevado) have been investigated so far (Möller and Schneider, 2010; Willis and others, 2012a, b). Consequently, little is currently known about glacier mass and volume changes in smaller glaciers across the Patagonian Andes. The state of small alpine glaciers is relevant, since they may contribute to a similar extent to the sea-level rise on a century timescale in comparison with larger ice masses, due to their shorter response time, coupled with large mass turnovers (Radic and Hock, 2011; Marzeion and others, 2012; Gardner and others, 2013; Giessen and Oerlemans, 2013).

Glacier mass-balance records in the Patagonian Andes remain to this day sparse. It is worth noting that hitherto no glaciological mass-balance programs have been carried out on any of the investigated glaciers of this study. In fact, the closest glacier with long-term measurements, Martial Este, is located more than $850 \mathrm{~km}$ to the southeast in Tierra del Fuego (Strelin and Iturraspe, 2007; Buttstädt and others, 2009). The lack of glacier in-situ measurements for glaciers in southern Patagonia remains so severe for such a densely glacierized area, that it has led to modeling glacier mass losses using energy-balance models (Schaefer and others, 2015).

In view of the above, the main purpose of this study is to focus on the smaller glaciers to the east of the NPI and SPI, by comparing the elevation and mass changes for the same time period (2000-12) as Willis and others (2012a, b). The results are also put into a broader context of glacier mass balance in the Patagonian Andes, thus reducing knowledge gaps in regards to the mass loss of smaller glaciers in the area. We also aim to detect glacier-thinning patterns as a function of a series of glacier morphometric factors (size, slope, orientation, mean elevation) and further analyze the influence of other glaciological characteristics such as debris covers, ice-calving and supra- and proglacial lakes.

\section{STUDY AREA}

The study area $\left(47^{\circ} 15^{\prime} \mathrm{S}-49^{\circ} \mathrm{S}, 71^{\circ} 45^{\prime} \mathrm{W}-73^{\circ} 20^{\prime} \mathrm{W}\right.$, Fig. 1$)$ is located in the Southern Patagonian Andes, at the international border between Chile (Región de Aysén) and Argentina (Santa Cruz Province). This region encompasses a large number of alpine-type glaciers located to the east of and in between the NPI and SPI, and also includes the northeastern tip of the SPI and one (Oriental) of its outlet glaciers. The largest glacierized massifs are the Monte San Lorenzo (3706 m, incidentally the highest point in the entire study area) and the Sierra de Sangra range (2200 m) (Fig. 1).

Glaciers in the area show diverse morphologies. While debris-free cirque glaciers are the most abundant type, a minor number of valley glaciers is also present, most notably the Río Oro, Río Lácteo and San Lorenzo Sur glaciers in the Monte San Lorenzo massif. These regenerated valley glaciers are mostly debris-covered and have proglacial lake terminating fronts (Falaschi and others, 2013).

The climate of this region is modulated to a great extent by the westerly flow, which drives humidity from the Pacific Ocean and produces precipitation maxima during the austral winter months (July-September, Garreaud, 2009). A strong W-E orographic precipitation gradient characterizes the Patagonian Andes and the eastern steppe-like plains. Precipitation maxima of up to $8-10 \mathrm{~m}$ w.e. are found over the SPI, while the easternmost reaches of the Patagonian Andes receive $<300 \mathrm{~mm} \mathrm{a}^{-1}$ (Villalba and others, 2003). West of the Andean ridge, Garreaud and others (2013) reported a 300-800 $\mathrm{mm}$ decrease in annual precipitation over north-central Patagonia for the 1968-2001 period, while to the east of the Andes precipitation changes were deemed not significant by the same authors. Central Patagonia shows a steady warming trend, with episodic cooler periods during the early-mid 1970s and early 21 st century (Masiokas and others, 2015).

While the temperature regime shows less extreme variations, environmental conditions range from fully maritime towards the west to mildly continental on the eastern slopes of the Argentinean Andes. This, in turn, affects mass balance and glacier response to climatic perturbations, since glaciers in more maritime environments will be more sensitive to rising temperatures, as the snow/rain ratio diminishes (Sagredo and Lowell, 2012). Moreover, the variability in climate conditions across the area might result in glaciers of diverse thermal regimes, from temperate in the western flank of the main Andean axis to polythermal towards the eastern side. Incidentally, glacier ELAs lie below $2000 \mathrm{~m}$ a.s.I., and glaciers extend far below the $0{ }^{\circ} \mathrm{C}$ isotherm (Condom and others, 2007; Sagredo and Lowell, 2012).

\section{DATA}

\subsection{Satellite imagery}

The orthorectified Landsat 7 ETM + scenes used here (acquisition dates 13 January, 1 and 8 March 2000; paths 231/232, rows 093/094) were obtained from the US Geological Survey (USGS) Earth Explorer portal (http://www.earthexplorer.usgs.gov). A mosaic was generated to exclude any cloud coverage in the individual scenes over the investigated glaciers. Because seasonal snow conditions were not everywhere optimal for glacier mapping (and varied between and within scenes), additional Landsat imagery from 1998 and 1999 (Table 1) was used for further examination of the seasonal snow conditions. In a context of sustained and widespread glacier retreat in the area (Falaschi and others, 2013; Masiokas and others, 2015), few if any glaciers were expected to have larger areas in the year 2000 compared with 1999.

The more recent satellite data originates from a Satellite Pour l'Observation de la Terre 5 (SPOT5) panchromatic image, acquired 8 March 2012. The orthorectified scene 


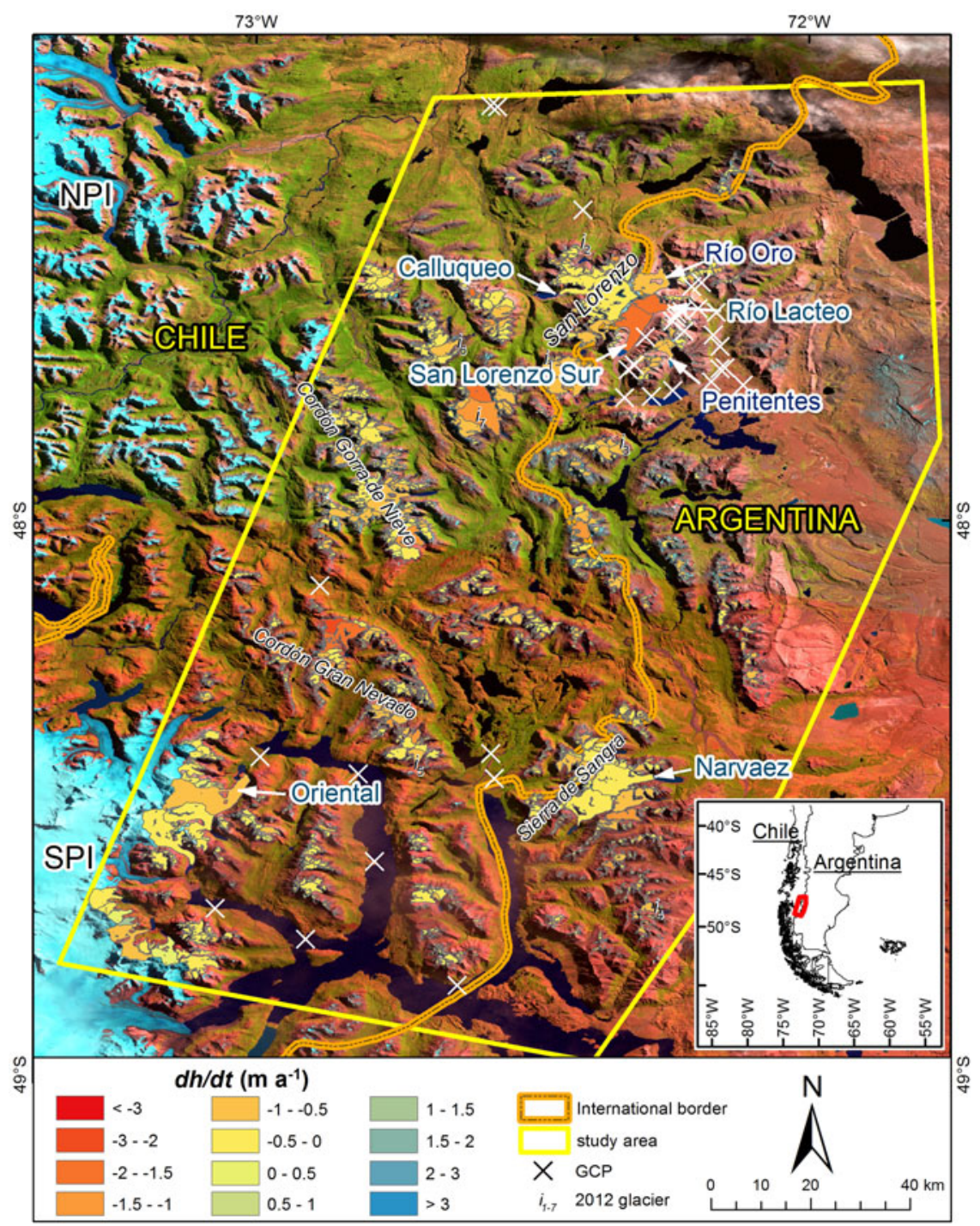

Fig. 1. Average glacier elevation changes for the entire study area. The location in South America is shown in the subset image with a red polygon. NPI and SPI are the Northern and Southern Patagonian Icefields, respectively. The $\mathrm{i}_{1-7}$ symbols correspond to the glaciers also inventoried for the year 2012 (see text for details).

was provided by the International Polar Year (IPY) SPIRIT (SPOT 5 stereoscopic survey of Polar Ice: Reference Images and Topographies) project (Korona and others, 2009).

\subsection{Shuttle radar topography mission C- and X- band synthetic aperture radar (SRTM) DEM}

The Shuttle Radar Topography Mission acquired data continuously between 11 and 22 February 2000 using interferometric synthetic aperture radar (SAR) sensors in C- and X-bands simultaneously (SIR-C and SIR-X, respectively). Void-filled tiles from the SRTM X-band were obtained from the Deutsches Zentrum für Luft und Raumfahrt (DLR) EOWEB Portal (http:// www.eoweb.dlr.de) at 1 arcsec resolution. Due to the low acquisition angle of the SRTM X-band, portions of the study area were not covered by the sensor and are therefore not comprised in the distributed elevation grids. These were filled using SRTM C-band grids, in such a way that each

Table 1. List of used Landsat imagery

\begin{tabular}{|c|c|c|c|c|}
\hline Sensor & Path/Row & $\begin{array}{l}\text { Acquisition date } \\
\text { yyyy-mm-dd }\end{array}$ & $\begin{array}{l}\text { Spatial resolution } \\
\mathrm{m}\end{array}$ & Purpose \\
\hline L7 ETM+ & 231/094 & 2000-01-13 & 30 & Inventory \\
\hline L7 ETM+ & $231 / 094$ & 2000-03-01 & 30 & Inventory \\
\hline L7 ETM+ & 232/093 & 2000-03-08 & 30 & Inventory \\
\hline L5 TM & $231 / 093$ & 1999-03-23 & 30 & Inventory check \\
\hline L5 TM & 231/094 & 1999-03-23 & 30 & Inventory check \\
\hline L5 TM & $232 / 093$ & 1998-03-20 & 30 & Inventory check \\
\hline L5 TM & 231/094 & 1998-03-20 & 30 & Inventory check \\
\hline SPOT 5 HRS & $120 / 308$ & 2012-03-08 & 5 & Inventory \\
\hline
\end{tabular}


glacier polygon contained elevation data from either one SRTM band or the other, but in no case from both of them. The non void-filled SRTM C-band DEM was obtained from the USGS Earth Explorer Portal (http://www.earthexplorer. usgs.gov), also at 1 arcsec resolution. In the following, we use the term SRTM when referring to the SRTM X DEM.

Elevation values in the SRTM C-band products refer to the EGM96 (Earth Gravitational Model 1996) geoid, whereas the SRTM X-band tiles refer to the WGS84 (World Geodetic System 1984) ellipsoid. To obtain scientifically sound elevation and mass-balance changes by means of DEM differencing, all the elevation data must be projected in the same vertical datum. This concern was resolved during the co-registartion procedure described in Section 4.3.

\subsection{Satellite Pour l'Observation de la Terre 5 (SPOT5) DEM}

A DEM was generated from a high-resolution stereoscopic sensor (HRS) SPOT5 stereo-pair that was provided by the International SPIRIT project (Korona and others, 2009). The present $40 \mathrm{~m}$ spatial resolution stereo-pair was acquired on 8 March 2012 and should therefore fairly reflect the conditions of the end of the ablation period in the Southern Andes. Le Bris and Paul (2015) report an absolute horizontal RMSE of $30 \mathrm{~m}$ and a vertical bias between -5.5 and $+3.5 \mathrm{~m}$ compared with ICESat for their study region in Alaska. Optical DEMs have no uncertainties related to the signal penetration, as do radar-derived DEMs, but are affected by the cloud cover problem and low contrast in shadow and highly reflective snow-covered areas (Pieczonka and others, 2011). For full technical details, generation and validation of the SPIRIT SPOT5 products see Korona and others (2009).

\subsection{Ground control points}

Elevation and slope related biases in mountain areas on SRTM DEMs have been reported by Berthier and others (2006). Validation and accuracy assessment of SRTM DEMs was carried out by means of independent, fieldsurveyed GCPs using the Global Navigation Satellite System (GNSS) technique. Selected landmarks were located on rock outcrops, large boulders and road intersections. Successive field campaigns were undertaken in the summers of 2010-12, when 21 GCPs were surveyed with a Trimble 5700 receiver. Additional GCPs were provided by Dr. Robert Smalley from CERI (Center for Earthquake Research and Information, Memphis State University, USA) for a total of 33 GCPs (Fig. 1). The altitudinal range covered by the GCPs spans between 160 and $1700 \mathrm{~m}$. Coordinates of these points were differentially post-processed using data from the private Cochrane GNSS continuous station. The mean horizontal and vertical precisions of these GCPs were 0.34 and $0.37 \mathrm{~m}$, respectively, and were considered sufficient for the purposes of this study.

The independent reference differential GCPs were compared with the corresponding coordinates' elevation values from the SRTM and SPOT5 DEMs and are provided as mean, standard deviation, standard error and RMSE (Fisher and Tate, 2006) (Table 2).
Table 2. Statistics for the validation of the DEMs against 33 reference GCP points. For a given value, the DEM elevation is subtracted from the GCP elevation

\begin{tabular}{lrrrc}
\hline DEM & Mean & STDV & RMSE & SE \\
& \multicolumn{1}{c}{$\mathrm{m}$} & \multicolumn{1}{c}{$\mathrm{m}$} & $\mathrm{m}$ & $\mathrm{m}$ \\
\hline SRTM X-band (master) & 10.52 & 8.07 & 13.36 & 1.40 \\
SRTM C-band (slave) & 5.89 & 10.19 & 11.64 & 1.31 \\
SPOT5 (slave) & -9.37 & 7.74 & 11.78 & 1.34 \\
& & & & \\
\hline
\end{tabular}

\section{METHODS}

\subsection{Glacier mapping}

A new glacier inventory for the year 2000 was prepared using a thresholded ratio Landsat ETM+ image mosaic (e.g. Paul and Andreassen, 2009; Bolch and others, 2010a; Rastner and others, 2012) (Table 1). Bare ice and snow were identified by means of the TM 3/TM 5 band ratio, with a threshold of DN > 2.6 (Racoviteanu and others, 2009). Further manual digitizing was necessary for mapping debris-covered ice and ice in cast shadows and for excluding rock outcrops.

For the compilation of our glacier inventory, overall uncertainties were estimated based on the glacier area buffer method as in Bolch and others (2010b). A buffer size of $\pm 7.5 \mathrm{~m}$ for the Landsat ETM+ scenes was selected, leading to an uncertainty of $\sim 5 \%$, which is slightly larger compared with other Landsat inventories (e.g. Paul and Andreassen, 2009; Rastner and others, 2012), but may be related to the comparatively small glaciers in our study area. For debris-covered ice delineation on Landsat imagery, it can be assumed that uncertainty in glacier outlines varies by only $\sim \pm 15 \mathrm{~m}$ (Paul and others, 2013).

Rolstad and others (2009) have pointed out that uncertainties in the individual glacier elevation change and mass budget determined using the geodetic method are dependent on the average glacier size. To investigate the resultant differences in the mass budgets, we manually digitized glacier outlines for seven glaciers for the year 2012 based on the SPOT 5 panchromatic scene (Fig. 1). These glacier outlines each represent one of the size classes of the glacier inventory (see Section 5).

\subsection{Glacier basins}

The method to derive glacier basins builds on those presented by Bolch and others (2010b) and Kienholz and others (2013). The sink-filled SPOT 5 DEM and the manually corrected glacier outlines served as input. In a first step, an ArcGIS model calculates a buffer of $500 \mathrm{~m}$ around each glacier polygon and subsets the DEM accordingly. Next, glacier basins are calculated by means of hydrological analysis. Since this procedure leads to many single and often unrealistic basins, the most relevant ones are selected by performing a spatial selection with the help of all the glacier outlines (Bolch and others, 2010b). To automatically merge remaining small basins, we extended the model with the following steps. At the beginning, a buffer of $300 \mathrm{~m}$ around all glacier entities is calculated and converted to a raster file. Subsequently outer raster values are lowered by $-50 \mathrm{~m}$, which leads to an artificial gutter. Thereafter, the lowest pixel of each gutter per basin is assigned (pour point). The pour points in the following are used for calculating 
another buffer of $200 \mathrm{~m}$ in raster format. With the aid of zonal statistics, a value is allocated to all basins containing the pour point. Finally, all drainage basins having the same ID (received from the pour points) are merged. Since this procedure dissolves only part of the glacier basins a second loop is added to merge more left over single basins.

The main errors of this method are due to DEM artifacts in the glacier accumulation areas, and where small glaciers without a distinct tongue cannot be separated from adjacent, larger glaciers. After the model run, manual corrections of the drainage basins are reduced but nevertheless necessary. We manually improved gross errors with the help of the shaded relief data, flow direction grid and the Landsat scenes.

\subsection{DEM co-registration}

When quantifying glacier elevation changes by means of DEM differencing, any mismatch in geolocation and/or vertical shift between tiles may result in elevation- or sloperelated biases (Nuth and Kääb, 2011). Here we have used the procedure of Berthier and others (2007) to correct misalignments between the SPOT5 DEM and each of the SRTM DEM bands. We found that this co-registration tool showed negligible differences compared with the Nuth and Kääb (2011) procedure in two test areas in the Andes (see also Paul and others, 2015).

Before DEM co-registration, both the SRTM C- and X-band tiles were mosaicked and projected in the UTM Zone 18 South projection. Since the SPOT 5 and SRTM C-band products refer to the EGM96 geoid and the SRTM X-band to the WGS84 ellipsoid, all of the elevation grids were put into the same vertical WGS84 datum. We used the SRTM X-band as the main data source as opposed to the SRTM Cband, since the latter penetrates deeper into snow due to its longer wavelength (Rignot and others, 2001; Gardelle and others, 2012). We calculated the elevation differences between the two SRTM bands over glacierized areas.

In the co-registration process, the master (SRTM) and slave (SPOT5) DEMs were first stacked in a single file, and then projected and resampled to the coarser DEM resolution (40 m here). Subsequently, the slave DEM was iteratively shifted horizontally until a minimum of the standard deviation of the elevation offset was reached.

\subsection{Calculation of elevation changes and mass balance}

Glacier elevation changes $(\mathrm{d} h / \mathrm{d} t)$ from February $2000\left(t_{0}\right)$ to March $2012\left(t_{1}\right)$ were calculated by differencing the SRTM and SPOT5 DEMs. Average $\mathrm{d} h / \mathrm{d} t$ values for $50 \mathrm{~m}$ elevation bins between 300 and $3700 \mathrm{~m}$ were calculated from the obtained elevation difference grid to determine the volume changes for each inventoried glacier. Despite the double SRTM coverage, remaining data voids $(\sim 30 \%)$ over glacierized areas had to be filled to obtain elevation change and volume values for the entire area. The calculated mean $\mathrm{d} h /$ $\mathrm{d} t$ values of each elevation bin were accordingly inserted into the data voids.

Filling the data voids in the elevation difference grid with the averaged elevation change for each altitude band diminishes the thinning rate (i.e. a more positive value). On the contrary, maintaining the data voids as no data values results in enhanced thinning, an assertion also made by Le Bris and Paul (2015). In order to understand the magnitude by which the mass budget changes between the filled and non-filled difference grids, we calculated the area-averaged mass balance for the raw (non-filled) and void-filled data.

The glacier elevation change values were converted into geodetic mass balance. First, the $\mathrm{d} h / \mathrm{d} t$ values and glacier area were used to calculate the volumetric ice losses $\left(\mathrm{km}^{3}\right)$ for the entire glacierized area. Subsequently, we calculated the geodetic mass balance (in $\mathrm{m}$ w.e.), assuming an average density conversion factor of $850 \pm 60 \mathrm{~kg} \mathrm{~m}^{-3}$ for all the material involved (Sapiano and others, 1998; Huss, 2013).

\subsection{Uncertainty assessment: DEM differences over non-glacierized terrain}

The effects of any systematic shifts between DEMs are minimized in the co-registration procedure, although elevation dependent biases might still be present resulting from the diverse pixel sizes of the different resolution DEMs and the resampling process (Paul, 2008; Paul and Haeberli, 2008). To account for these elevation- and slope-dependent biases, curvature corrections have been carried out in some cases (e.g. Gardelle and others, 2012, 2013). In our case, we did not find any systematic elevation-dependent bias over stable terrain, probably owing to the fairly comparable cell size of the SRTM and SPOT5 DEMs. Although no corrections for elevation-dependent biases have been carried out in this study, pixel values exceeding $\pm 2 \sigma$ in the difference grid were treated as outliers and were therefore removed.

Elevation differences over stable terrain were calculated in a buffer zone outside the glaciers, of the same area as each glacier polygon. A similar approach, though with a larger mask, was undertaken by Carturan and others (2013) and Fischer and others (2015). In our study region, implementing exceedingly large buffer areas presents two main inconveniences. (1) Sharp ridges such as lateral moraines (particularly Little Ice Age) have high-frequency slope variations, which coarse DEMs are relatively incapable of reproducing. In such spots, the curvature (first derivative of the slope) is high, and the surface elevation is underestimated in the coarser DEM (Gardelle and others, 2013). The effect of different cell size on DEMs will be therefore maximized. (2) Because the radar pulse can be reflected by the canopy surface in forested areas (Sexton and others, 2009), the true surface (terrain) elevation might not be adequately captured if the buffer zone extends into densely vegetated areas.

Slope-wise, overly steep areas on stable terrain are not representative of glaciers, which normally have slopes gentler than a given threshold in most of their area (Rolstad and others, 2009). We have therefore excluded them from the uncertainty calculation as follows. The mean slope of the total glacierized area was calculated as $21^{\circ}$, whereas the standard deviation was $12^{\circ}$. Hence, we used a $33^{\circ}$ slope threshold and masked the buffer areas around the glaciers with the slope buffers. For the SRTM C-band, the standard deviation $\sigma$ of the elevation differences with the SPOT5 DEM in the buffered areas was $13.6 \mathrm{~m}$ and for the SRTM Xband was $14.1 \mathrm{~m}$.

The distribution of the uncertainty in elevation changes is known to vary depending on the slope, roughness and the presence of low-contrast areas such as deep shadows (Zemp and others, 2013), and uncertainty is expected to increase at higher altitudes. Within the aforementioned buffer areas, the uncertainty was hence first calculated for each of the $50 \mathrm{~m}$ elevation bins that cover the 300-3700 m 
elevation range of the glacier area. For each altitude band, the standard error was calculated following the approach of Gardelle and others (2013):

$$
S E_{\Delta z . \text { rand }}=\frac{\sigma_{\Delta z}}{\sqrt{n_{\mathrm{eff}}}}
$$

where $\sigma_{\Delta z}$ is the standard deviation of the elevation differences between DEMs over stable terrain $(\Delta z)$ per elevation band and $n_{\text {eff }}$ the effective sample size or number of degrees of freedom. $N_{\text {eff }}$ is lower than the total number of cells in the off-glacier buffer areas and accounts for the distance of spatial autocorrelation of the elevation differences (Rolstad and others, 2009; Zemp and others, 2013)

$$
n_{\mathrm{eff}}=\frac{n_{\mathrm{tot}} \cdot R}{2 d}
$$

where $n_{\text {tot }}$ represents the total number of cells in each elevation band, $R$ the pixel size $(40 \mathrm{~m})$ and $d(80 \mathrm{~m})$ the distance of spatial autocorrelation, obtained by means of the Moran's I autocorrelation index (Ruiz and others, 2016).

The mean difference between DEMs over non-glacierized terrain represents the systematic uncertainty for the volumetric changes and can be of negative or positive sign depending on whether it is subtracted or added to the volume balance (Koblet and others, 2010):

$$
\varepsilon_{\Delta z . \mathrm{sys}}=\frac{\sum_{1}^{n} \Delta z}{n_{\mathrm{tot}}}
$$

The resultant annual elevation change rate $\mathrm{d} h / \mathrm{d} t$ is hence expressed as:

$$
\frac{\mathrm{d} h}{\mathrm{~d} t}=\frac{\Delta h_{\mathrm{g}}+\varepsilon_{\Delta \mathrm{zr} . \mathrm{sys}} \pm S E_{\Delta z . \mathrm{rand}}}{\mathrm{d} t}
$$

$\Delta z_{\mathrm{g}}$ being the sum of all the elevation difference values for the total glacier area at pixel scale and $d t$ the number of years.

The final random uncertainty for the volume balance $\left(\sigma_{\mathrm{vol}}\right.$. rand) results from the cumulated firn density assumptions $\left(\sigma_{\text {density.rand }}\right)$ and DEM differences over stable terrain $\left(\sigma_{\text {st-terr. }}\right.$ rand) as follows (Fig. 2):

$$
\sigma_{\text {vol.rand }}=\sqrt{\sigma_{\text {density.rand }}^{2}+\sigma_{\text {st-terr.rand }}^{2}}
$$

\section{RESULTS}

\subsection{Glacier inventory}

We mapped a total of 2253 glaciers larger than $0.01 \mathrm{~km}^{2}$, with an area of $1314 \pm 66 \mathrm{~km}^{2}$. The vast majority of the glaciers are relatively small $\left(<0.5 \mathrm{~km}^{2}\right)$ cirque glaciers, the exceptions being the Oriental outlet glacier from the SPI and a few valley glaciers (e.g. Río Lácteo, Rio Oro, San Lorenzo Sur, Narvaez). The largest non-outlet glacier is Calluqueo glacier $\left(50.9 \mathrm{~km}^{2}\right)$, and the mean glacier area is $0.58 \mathrm{~km}^{2}$.

Only the three major valley glaciers in the San Lorenzo massif are debris covered. Coupled with other minor portions

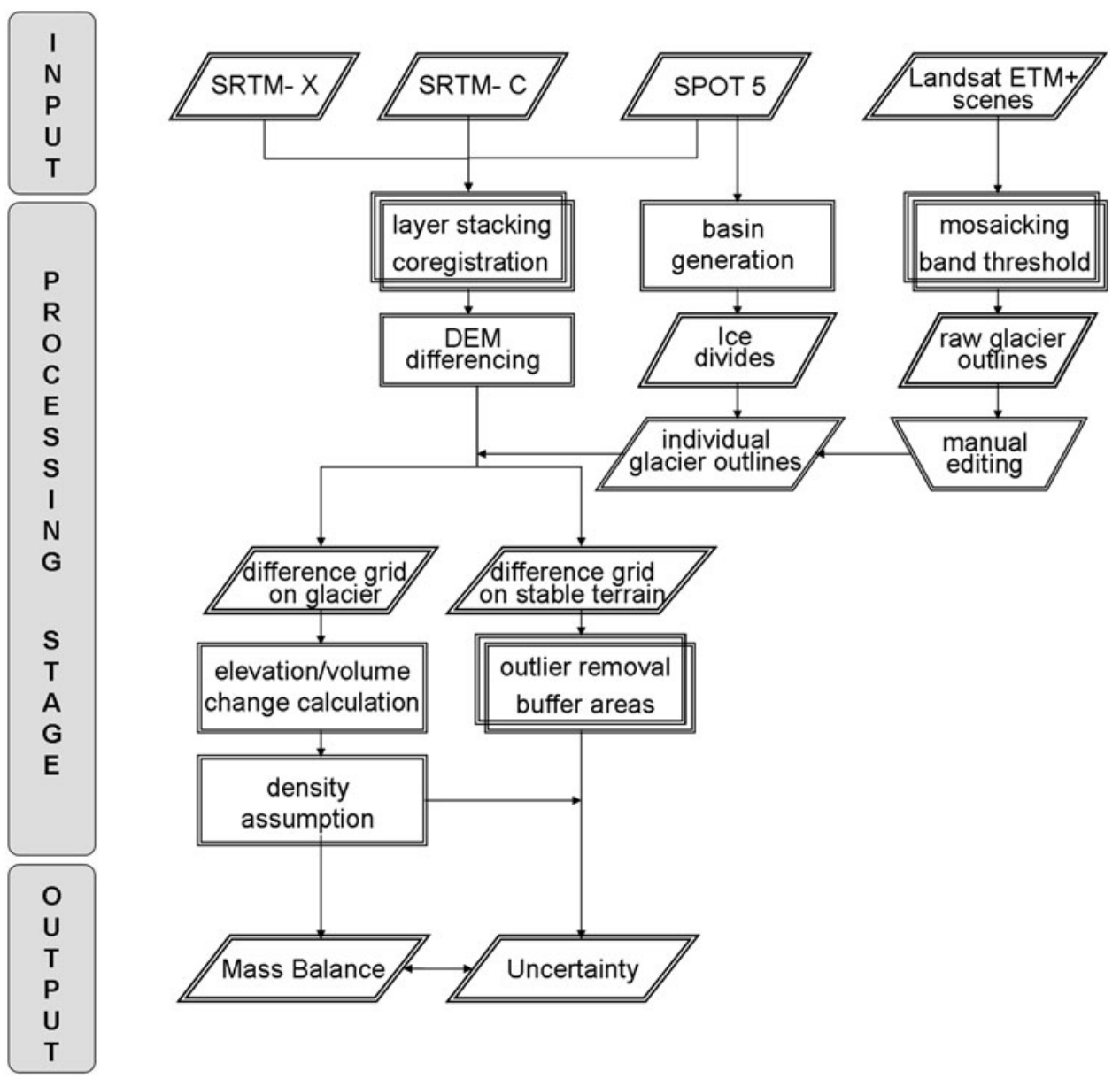

Fig. 2. Schematic workflow and main steps for the retrieval of the mass balance and the associated uncertainty. Parallelogram, data; rectangle, process; inverted trapezium, manual process. 
of smaller glaciers spread across the study area, the debriscovered ice area accounts for $21.5 \mathrm{~km}^{2}(\sim 0.02 \%$ of the total glacierized area). The primary source of nourishment of these regenerated glaciers is by avalanche feeding. Debris covers mainly occupy the flat portions of the glaciers, whereas little debris accumulates on steeper glaciers (Frey and others, 2012).

From the total of 2253 inventoried glaciers, merely eight of them are proglacial lake calving (San Lorenzo Sur, Río Lácteo, Narváez, Oriental, three unnamed glaciers in the Narvaez and Gorra de Nieve massifs, and an additional unnamed glacier in the Cerro Penitentes area East of San Lorenzo Sur).

A strong relationship exists between glacier morphology (cirque vs. valley or outlet glaciers) with respect to the distribution of glacier size and number (Fig. 3): $\sim 89 \%$ of the investigated glaciers are smaller than $1 \mathrm{~km}^{2}$ and only $2 \%$ are larger than $5 \mathrm{~km}^{2}$. Nevertheless, the relative contribution to the total glacier area is $25 \%$ for the former and $29 \%$ for the latter.

\subsection{Glacier elevation changes and mass balance}

The mean, area-weighted elevation change for the entire study area is $-0.52 \pm 0.35 \mathrm{~m} \mathrm{a}^{-1}$, while the total volume loss of the entire study region was of $0.71 \pm 0.55 \mathrm{~km}^{3} \mathrm{a}^{-1}$. This yielded a geodetic mass-balance estimation of $-0.46 \pm 0.37 \mathrm{~m} \mathrm{w.e.} \mathrm{a}^{-1}$ for the entire area. The raw $\mathrm{d} h / \mathrm{d} t$, based on the non-filled difference grid, was determined as $-0.6 \pm 0.17 \mathrm{~m} \mathrm{a}^{-1}$.

The surface elevation of the vast majority of the glaciers $(\sim 80 \%)$ has lowered between 0 and $-2 \mathrm{~m} \mathrm{a}^{-1}$ over the 2000-12 period (Fig. 1). Nevertheless, the variability in glacier-specific elevation change within a single mountain ridge was relatively high, as shown in the example of Cordón Gran Nevado (Figs 1, 4). Glacier thinning is greater and more widespread below $1100 \mathrm{~m}$ a.s.l. but decreases rapidly with elevation (Fig. 5). Indeed, some elevation gains occur above $3000 \mathrm{~m}$ a.s.l. in small parts of the accumulation area of Calluqueo glacier on Monte San Lorenzo (Fig. 4).
Proglacial lake calving glaciers in the area exhibit a relatively wide range of thinning rates, from $-0.28 \mathrm{~m} \mathrm{a}^{-1}$ for the Narváez glacier to $-1.9 \mathrm{~m} \mathrm{a}^{-1}$ for Río Lácteo and a mean lowering rate of $-0.96 \mathrm{~m} \mathrm{a}^{-1}$. Yet, the highest lowering rates among them correspond to lake calving glaciers that additionally have a debris-covered tongue (Table 3). Indeed, and despite the very small proportion of the total glacierized area occupied by debris cover, thinning in the debris-covered portions is greater with respect to both the calving-type and full area averages. A mean $\mathrm{d} h / \mathrm{d} t$ of $-1.54 \mathrm{~m} \mathrm{a}^{-1}$ was determined for the debris-covered areas (accounting for $21.5 \mathrm{~km}^{2}$ in total), which is three times that of the entire study area. Discarding the calving and debriscovered glaciers, the averaged lowering rate of the debrisfree glaciers is therefore reduced to $-0.47 \mathrm{~m} \mathrm{a}^{-1}$.

When analyzing the relation between the elevation change rate for individual glaciers and morphometric factors, no strong correlation was found $(\alpha=0.05)$ for glacier size $(r=-0.13)$ though in general, smaller glacier size classes show a great scatter in $\mathrm{d} h / \mathrm{d} t$ rates, which is reduced for the larger glaciers (see Fig. 6 and Table 4); correlations were also weak for mean slope $(r=-0.11)$ and median elevation $(r=0.06)$. The great variability on any of the $\mathrm{d} h / \mathrm{d} t$ vs. morphometric factor plots is condensed when the data are clustered in 5\% quantiles as in Fischer and others (2015). After the mean $\mathrm{d} h / \mathrm{d} t$ rate is calculated for each of the 20 classes, the relation between thinning rates and the morphometric indices becomes more apparent. Much stronger and significant correlations arise for glacier area $(r=-0.62)$, mean aspect $(r=0.62)$ and mean slope $(r=-0.74)$, while the weak correlation $(r=0.44)$ for median elevation was found not to be statistically significant.

\section{DISCUSSION}

\subsection{Variability in glacier elevation change}

The elevation change rates of the investigated glaciers might be related to a number of both methodological and glaciological factors and processes. As reported above, most

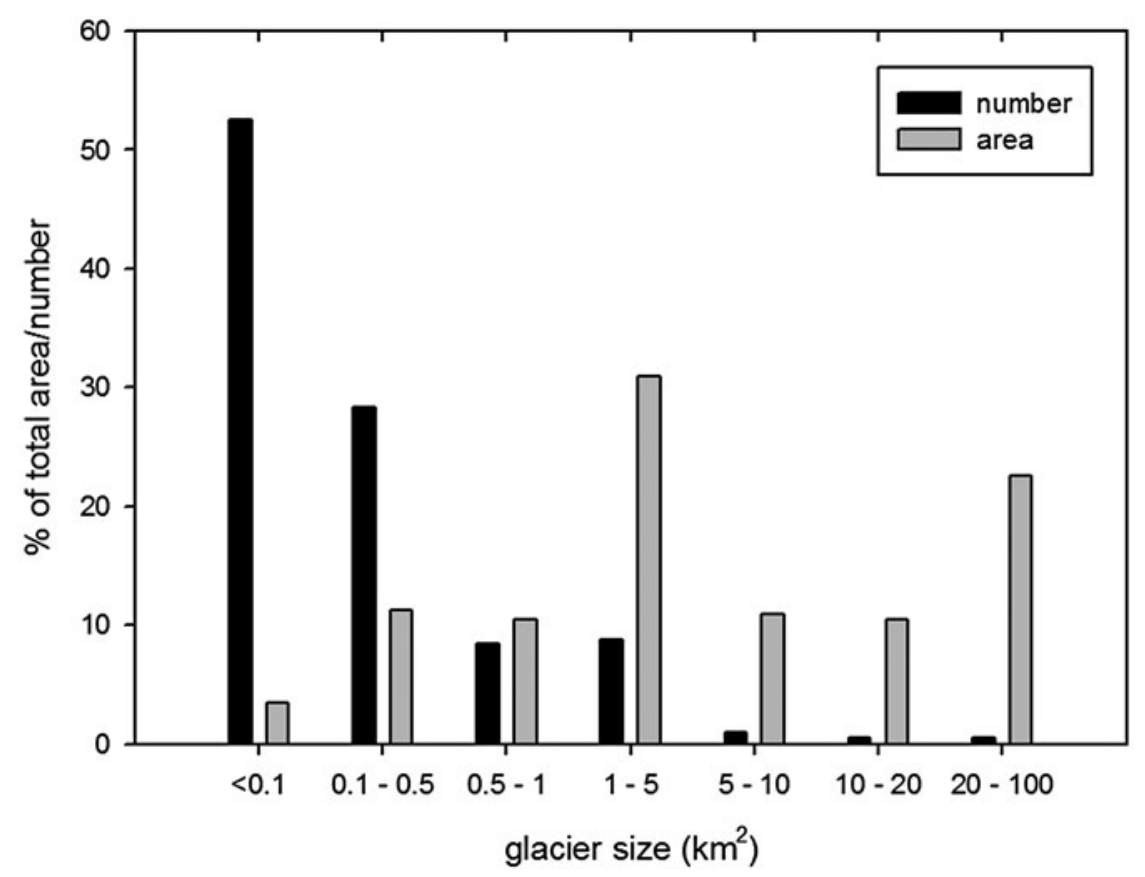

Fig. 3. Percentage contribution to glacier area (grey bars) and number (black bars) per glacier size class. 


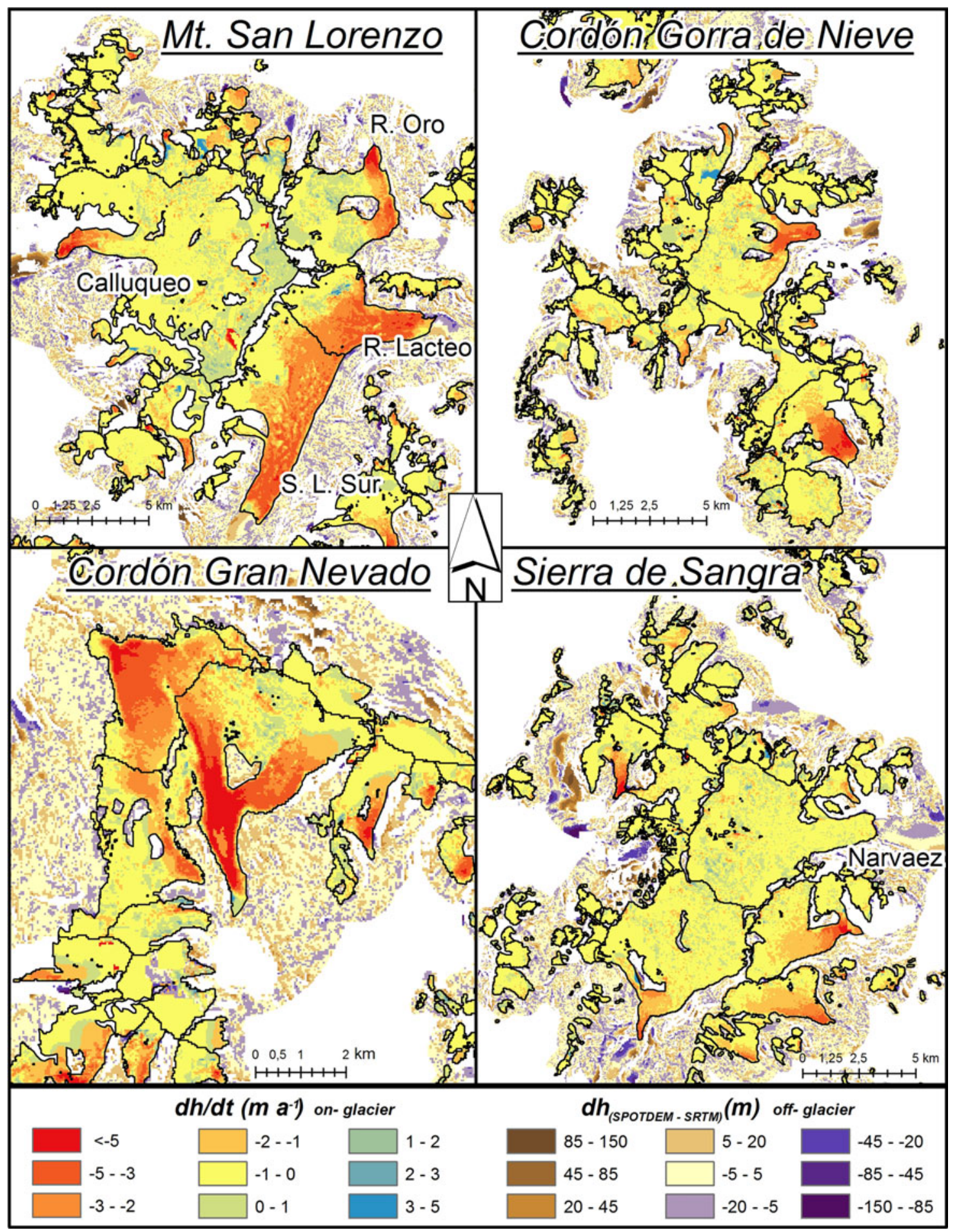

Fig. 4. Detailed view of elevation changes $(\mathrm{d} h / \mathrm{d} t)$ and DEM differences in meters over stable terrain for four mountain ranges in the study area.

glaciers $(80 \%)$ in the area have thinned between 0 and $-2 \mathrm{~m}$ $\mathrm{a}^{-1}$ over the study period. From the remaining $20 \%$, no more than nine glaciers have greater lowering rates, whereas the remaining glaciers show elevation gains.

No positive $\mathrm{d} h / \mathrm{d} t$ values were found at glacier terminuses, which would indicate advancing fronts or glacier surges. On the contrary, positive $\mathrm{d} h / \mathrm{d} t$ values are located at glacier limits, mostly below mountain ridges and steep faces that remain in the radar shadow zone, or alternatively, in accumulation areas with low contrast where the optical stereocorrelation fails (Frey and Paul, 2012; Gardelle and others, 2013). Most probably, glacier thickening in some units appears as the consequence of DEM artifacts and their increasing effect on the average elevation change of smallto medium-sized glaciers (Le Bris and Paul, 2015). In general, the smaller the glacier, the higher the chances for a DEM artifact to considerably alter a glacier's $\mathrm{d} h / \mathrm{d} t$ rate. The same applies to small glaciers $\left(<0.1 \mathrm{~km}^{2}\right)$ with exceptionally high thinning rates (e.g. $-4.11 \mathrm{~m} \mathrm{a}^{-1},-3.46 \mathrm{~m} \mathrm{a}^{-1}$ ).

The positive elevation changes in the accumulation area of Calluqueo glacier, while spatially limited considering the total glacier area, do not coincide with DEM artifacts. They have nevertheless a relatively large areal extent, enough to be considered as real. Since Monte San Lorenzo is the only massif with elevation exceeding $3000 \mathrm{~m}$ a.s.I. it was not possible to identify glacier thickening in the accumulation areas 


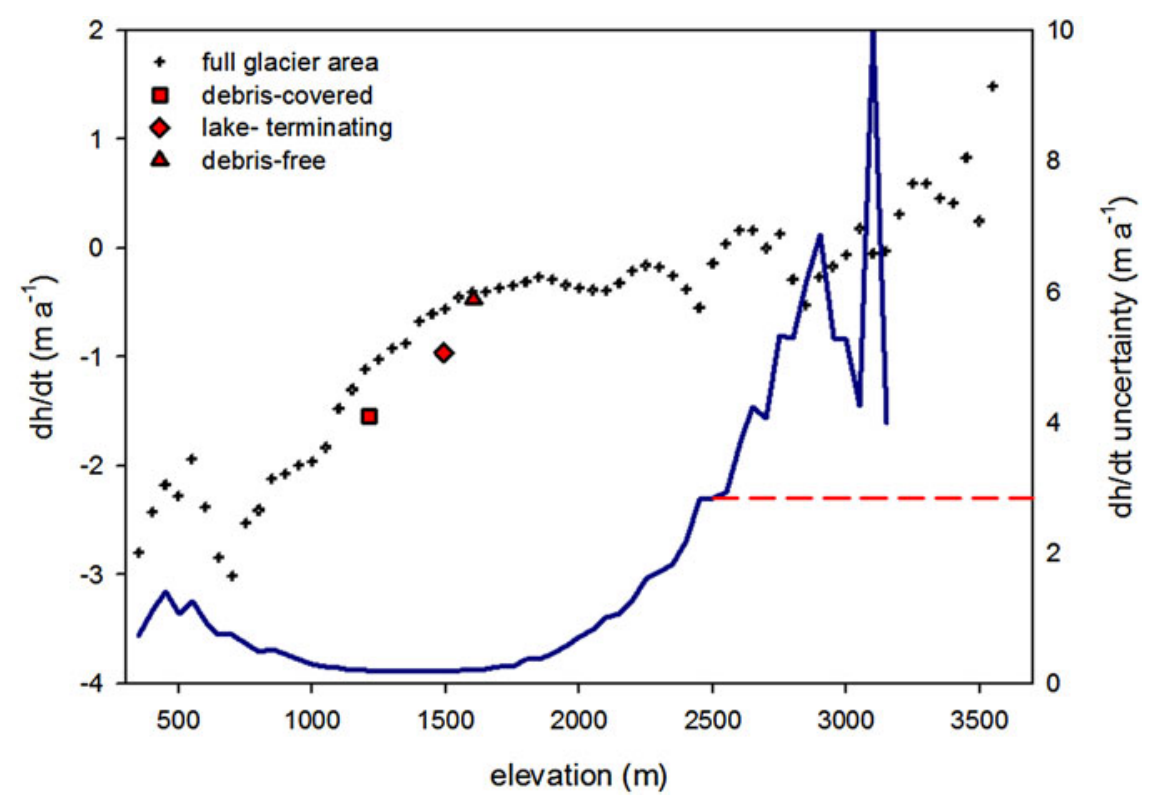

Fig. 5. Mean $\mathrm{d} h / \mathrm{d} t$ for $50 \mathrm{~m}$ elevation bins over the entire glacierized area (black crosses), including the average $\mathrm{d} h / \mathrm{d} t$ for debris-covered glaciers, square; calving glaciers, diamond; and debris-free glaciers, triangle. The blue line shows the uncertainty distribution with altitude. The uncertainty increases substantially above $2500 \mathrm{~m}$, owed to the impact of DEM artifacts on the decreasing number of offglacier pixels at higher elevations. For elevation bins $>2500 \mathrm{~m}$, a constant $\mathrm{d} h / \mathrm{d} t$ uncertainty value was used (red dashed line).

of other large glaciers in other massifs of the study area (see Fig. 5).

In terms of the correlations between elevation change and glacier morphometric indices, the negative $\mathrm{d} h / \mathrm{d} t$ vs. glacier size correlation indicates that the greatest thinning rates are concentrated on glaciers of relatively large size, i.e. valley glaciers flowing into valleys at low elevation, where temperatures are usually higher than on mountain flanks and ablation is enhanced. On the other hand, the positive correlation between $\mathrm{d} h / \mathrm{d} t$ and median elevation means that thinning rates tend to be less negative with elevation. Median elevation, in turn, can be taken as a rough proxy for the glacier balanced-budget ELA (Braithwaite and Raper, 2009), which is primarily dependent on continentality. Glaciers in a cooler and moister maritime environment are likely more sensitive to changes in temperature and precipitation compared with those in a warmer, drier more continental regime (Braithwaite and Raper, 2007). Consequently, they are expected to have a more negative mass balance in a warming world (Hoelzle and others, 2007).

Further insight into the elevation changes in the region is provided by other glacier characteristics, such as the presence of debris-covered ice, pro- and supraglacial lakes, calving fronts, gradient and flow rate of the lowermost portions of the glacier tongues, and their status as regenerated tongues.

The largest lowering rates are to be found on mostly debris-covered valley glaciers with regenerated tongues and lake terminating fronts (San Lorenzo Sur, Río Lácteo and Penitentes). The San Lorenzo Sur glacier additionally has a large number of supraglacial melt-ponds. While thick ( 0 to $>2 \mathrm{~m}$ observed in the field) debris layers should hamper ablation (Benn and Evans, 2010), the presence of pro- and supraglacial lakes has the opposite effect, since they represent heat absorbing spots on the glacier surface (Lüthje and others, 2006). Unfortunately, the size of supraglacial lakes on San Lorenzo Sur glacier was too small compared with the $40 \mathrm{~m}$ resolution DEMs to establish whether they coincided with enhanced thinning. In contrast, a milder lowering rate was found for Río Oro glacier, which is a regenerated debris-covered glacier, but has a land terminating front and lacks supraglacial ponds. In the Cordón Gorra de Nieve, the mostly debris-free glaciers with calving terminuses have lower thinning rates compared with the

Table 3. Comparison for ten glaciers of topographic and glaciological characteristics with elevation changes

\begin{tabular}{|c|c|c|c|c|c|c|}
\hline Glacier & $\mathrm{d} h / \mathrm{d} t$ & $\begin{array}{c}\text { Median elevation } \\
\mathrm{m}\end{array}$ & $\begin{array}{c}\text { Min elevation } \\
\mathrm{m}\end{array}$ & Debris cover & Longitudinal profile & Calving \\
\hline San Lorenzo Sur & -1.8 & 1308 & 1003 & Yes & Regenerated & Yes \\
\hline Río Lácteo & -1.95 & 1335 & 1128 & Yes & Regenerated & Yes \\
\hline Penitentes & -1.36 & 2045 & 1305 & Yes & Regenerated & Yes \\
\hline Río Oro & -0.81 & 1780 & 829 & Yes & Regenerated & No \\
\hline Gorra de Nieve unnamed 1 & -0.73 & 1452 & 650 & Partial & Even, regular & Yes \\
\hline Narvaez & -0.28 & 1667 & 782 & No & Even, regular & Yes \\
\hline Narvaez unnamed & -0.48 & 1444 & 882 & No & Even, regular & Yes \\
\hline Oriental & -0.61 & 1591 & 292 & No & Even, regular & Yes \\
\hline Cordón Gran Nevado unnamed & -1.67 & 1190 & 517 & No & Even, regular & No \\
\hline
\end{tabular}



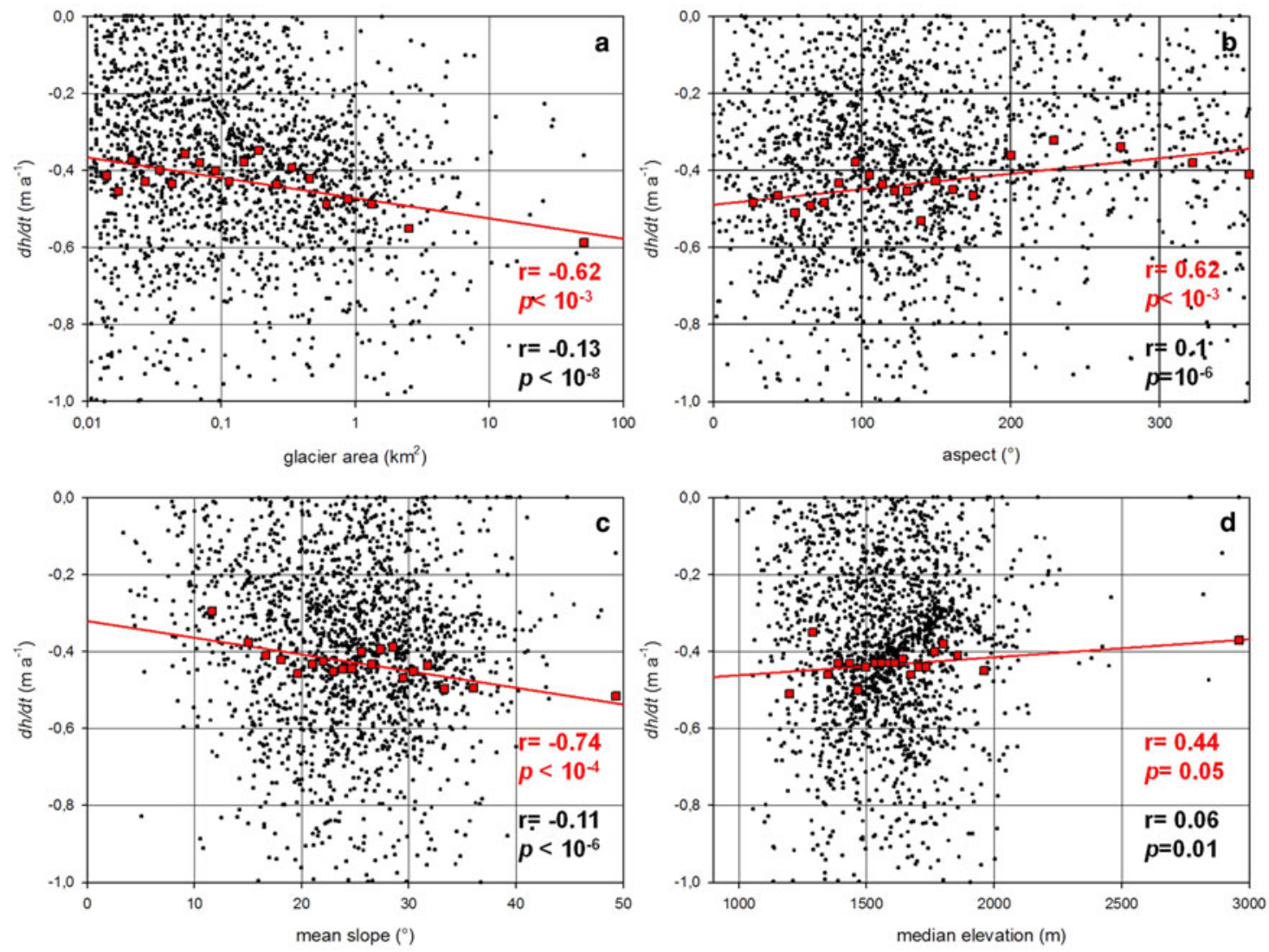

Fig. 6. Average annual elevation changes in $\mathrm{m} \mathrm{a}^{-1}$ as a function of glacier morphometric parameters: (a) glacier area (b): mean aspect (c) mean slope and (d) mean elevation. Non-grouped data are shown in black dots and the mean $\mathrm{d} h / \mathrm{d} t$ rates for $5 \%$ quantiles in blue squares. The red trendlines apply to the grouped data.

aforementioned group of calving, debris-covered glaciers (Table 3), though still higher than the full study area average.

The abundance of land terminating, debris free and nonregenerated glaciers in the area is probably reflected in the mainly lower, total area averaged thinning rate $(-0.52$ $\left.\mathrm{m} \mathrm{a}^{-1}\right)$. Although glaciers with these characteristics and high thinning rates naturally exist, the hypsometric distribution of the individual glaciers is probably the main controlling factor for this major group of glaciers.

The slope and flow rates of the glacier tongues are also related to the process of glacier decline. In general, glacier shrinkage, caused by reduced precipitation and increased ablation, favors the growth and expansion of glacial lakes. Yet on debris-covered glaciers, the process is enhanced by the usually gentle slopes and slow flow rates of the glacier tongues (Quincey and others, 2007). Both field observations

Table 4. Glacier mean elevation changes and standard deviation per size class

\begin{tabular}{lrcc}
\hline $\begin{array}{c}\text { Glacier area } \\
\mathrm{km}^{2}\end{array}$ & $n$ & $\begin{array}{c}\text { mean dh/dt } \\
\mathrm{m} \mathrm{a}^{-1}\end{array}$ & $\begin{array}{c}\text { std dev } \\
\mathrm{m} \mathrm{a}^{-1}\end{array}$ \\
\hline $0.01-0.05$ & 838 & -0.17 & 0.59 \\
$0.05-0.1$ & 345 & -0.19 & 0.44 \\
$0.1-0.5$ & 637 & -0.31 & 0.36 \\
$0.5-1$ & 190 & -0.44 & 0.22 \\
$1-5$ & 200 & -0.50 & 0.35 \\
$5-10$ & 22 & -0.61 & 0.52 \\
$10-50.9$ & 21 & -0.78 & 0.58 \\
\hline
\end{tabular}

and remote-sensing data have in fact demonstrated that the glacier surface gradient provides the boundary conditions for lake formation and expansion, whereas the exact location of lake initiation is mainly controlled by local variations in glacier velocity and surface morphology (Bolch and others, $2008 b)$. For the total debris-covered ice area, we calculated an average slope of $11^{\circ}$, whereas the mean slope for the full glacier area is $21^{\circ}$. Although Quincey and others (2007) have suggested $\mathrm{a}<2^{\circ}$ threshold for lake formation, the proglacial lakes of the Río Lácteo and San Lorenzo Sur are indeed expanding rapidly (Falaschi and others, 2013), and are most probably contributing to the enhanced thinning of these glaciers.

When looking at the longitudinal profile and hypsometric curves of the San Lorenzo Sur, Río Lácteo and Penitentes glaciers (see Falaschi and others, 2013), a common feature stands out: most of the glacier area is concentrated at low elevations in gently-sloping tongues. As a result, there is a strong chance for the glacier ELAs to lie above most of the glacier area. This, in turn, might result in low accumulation area ratios (Falaschi and others, 2013), which are indicative of glaciers in disequilibrium (Bakke and Nesje, 2011).

\subsection{Comparison with the NPI, SPI, Patagonian Andes and other glacierized mountain ranges}

The mean $\mathrm{d} h / \mathrm{d} t$ of $-0.52 \pm 0.35 \mathrm{~m} \mathrm{a}^{-1}$ for the study area is much lower than the extreme average ice surface lowering rates of $-1.3 \pm 0.1 \mathrm{~m} \mathrm{a}^{-1}$ and $-1.8 \pm 0.1 \mathrm{~m} \mathrm{a}^{-1}$ calculated in the same period for the NPI and SPI, respectively, by Willis and others $(2012 a, b)$. This means that for exactly the 
Table 5. Changes in mass balance for seven glaciers as a function of glacier size using the averaged $t_{0}-t_{1}$ glacier area

\begin{tabular}{|c|c|c|c|c|c|c|c|}
\hline$i$ & $\begin{array}{c}\text { Area } \\
\mathrm{km}^{2}\left(t_{0}\right)\end{array}$ & $\begin{array}{c}\text { Area } \\
\mathrm{km}^{2}\left(t_{1}\right)\end{array}$ & $\begin{array}{l}\text { Average area } \\
\mathrm{km}^{2}\end{array}$ & $\begin{array}{c}\text { Reduction } \\
\%\end{array}$ & $\begin{array}{c}\text { Mass balance } \\
\text { m w.e. } \mathrm{a}^{-1}\left(\text { area }_{t 1}\right)\end{array}$ & $\begin{array}{c}\text { Mass balance } \\
\text { m w.e. } \mathrm{a}^{-1}\left(\text { area }_{\text {average }}\right)\end{array}$ & $\begin{array}{c}\text { Mass balance difference } \\
\%\end{array}$ \\
\hline 1 & 0.04 & 0.02 & 0.03 & 50 & -0.65 & -0.86 & 32 \\
\hline 2 & 0.09 & 0.07 & 0.08 & 17 & -0.40 & -0.44 & 10 \\
\hline 3 & 0.49 & 0.43 & 0.46 & 12 & -0.23 & -0.24 & 4 \\
\hline 4 & 0.98 & 0.82 & 0.90 & 16 & -0.46 & -0.50 & 9 \\
\hline 5 & 3.76 & 3.47 & 3.61 & 8 & -0.62 & -0.64 & 3 \\
\hline 7 & 24.67 & 23.72 & 24.19 & 4 & -1.05 & -1.07 & 2 \\
\hline
\end{tabular}

The mass-balance $\left(\right.$ area $_{t 1}$ ) column refers to the glacier mass balance considering the glacier size at $t_{1}(2012)$, whereas the mass-balance (area ${ }_{\text {average }}$ column corresponds to mass-balance calculation using the averaged 2000-12 glacier size.

same 2000-12 observed period in this study, the thinning rates of the SPI and $\mathrm{NPI}$ are respectively more than triple and double that of the smaller alpine glaciers located further east. At the individual glacier scale, maximum $\mathrm{d} h / \mathrm{d} t$ rates of $-28 \mathrm{~m} \mathrm{a}^{-1}$ and up to $-57 \pm 13 \mathrm{~m} \mathrm{a}^{-1}$ were reported for essentially the same time period (Rignot and others, 2003; Willis and others, 2012b), which far exceed the more subdued 0 to $-2 \mathrm{~m} \mathrm{a}^{-1}$ thinning rates found in this study.

At first glance, the above results might surprise, though when seen in terms of glacier morphology and the factors contributing to glacier shrinkage, the interpretation is easier to follow.

The outlet glaciers of the Patagonian icefields are mainly large tidewater and freshwater calving glaciers (glaciers with sea- or lake-terminating snouts such as the Perito Moreno, Jorge Montt, Upsala, Viedma, Pío XI glaciers), which have a cyclic behavior that deviates from the response to climatic variability (Yde and Paasche, 2010; Wilson and others, 2016). During this highly dynamic cycle, some calving glaciers may exhibit phases of slow advance or rapid, unstable retreat, the latter accompanied by particularly high thinning rates and calving fluxes (Post and others, 2011; Rivera and others, 2012). The rapid mass loss phase is driven by strong feedback mechanisms between the tightly coupled ice resupply and calving rates. Owing to the highly pressurized subglacial hydraulic systems found in over-deepenings behind the terminal moraines, glacier buoyancy near the terminus is increased, promoting in turn glacier retreat driven by high basal water pressures (Post and others, 2011). Certainly, the vast majority of the investigated glaciers in this study have land-terminating terminuses, so their behavior should be largely related to climate forcing and they should have much lower thinning rates. Yet some of them (e.g. San Lorenzo Sur, Río Lácteo, Penitentes), do have (small) proglacial lake terminating snouts, which in turn has led to great iceberg production and rapid frontal retreat (Falaschi and others, 2013).

Frequently, previously published studies dealing with glacier mass budget around the globe have estimated the mass-balance rates for the Southern Patagonian Andes as a whole, including the SPI and NPI. Ivins and others (2011) and Jacob and others (2012), to name a few, have estimated the mass balance of the region as $-29 \pm 10 \mathrm{Gt} \mathrm{a}^{-1}$ (2003-09) and $-23 \pm 9 \mathrm{Gt} \mathrm{a}^{-1}$ (2003-10). For our comparatively smaller study area, a mass loss rate of $-0.6 \pm 0.48 \mathrm{Gt} \mathrm{a}^{-1}$ clearly shows that in the Patagonian Andes, ice loss is largely concentrated in the NPI and SPI.

In other mountain ranges around the globe, and in terms of glacier size and morphology, debris cover and latitude, the
European Alps host probably the glaciers most similar to those investigated in this study. There, the average mass balance has been much lower for a similar time period than in the Patagonian Andes $\left(-1.06 \pm 0.17 \mathrm{~m}\right.$ w.e. $\mathrm{a}^{-1}$ (2003-09) Gardner and others, 2013; -2 $\pm 3 \mathrm{Gt} \mathrm{a}^{-1}$ (200310) Jacob and others, 2012). Our estimates are nevertheless in accordance with global estimates of $-0.55 \mathrm{~m}$ w.e. $\mathrm{a}^{-1}$ calculated between 1996 and 2005 (Cogley, 2009) and -0.50 \pm 0.04 m w.e. $\mathrm{a}^{-1}$ derived from Gardner and others (2013).

\subsection{Radar penetration and further uncertainty considerations}

The Interferometric Synthetic Aperture Radar (InSAR) signal interacts at variable depth with snow, firn and glacier ice, radar penetration depending on the snowpack wetness, radar frequency and wavelength, among others (Willatt and others, 2010). In the case of SRTM, it has been suggested that the C-band derived DEM may underestimate glacier elevation compared with the X-band, due to the deeper penetration of its radar pulse into the snowpack - several meters) at the $5.6 \mathrm{~cm}$ wavelength (Rignot and others, 2001; Gardelle and others, 2012). Willis and others (2012b) investigated the effect of radar penetration in the SPI, finding an average $2 \mathrm{~m}$ difference between the two SRTM products.

Also, the radar pulse penetrates much more deeply into dry snow and firn compared with exposed ice (Rignot and others, 2001). Because SRTM was acquired in mid-winter in the Northern Hemisphere (February 2000), when a substantial yet undetermined amount of fresh snow might have fallen on the glacier surface, some authors have implemented corrections for radar pulse penetration into snow before proceeding with elevation and volume change assessments (e.g. Rignot and others, 2001; Gardelle and others, 2013; Kääb and others, 2015). In the Southern Andes, however, SRTM was acquired during the ablation period, when the glacier surface was ice or wet snow, thus preventing the penetration of the radar wave. Jaber and others (2013) confirm in fact that in the accumulation area of the SPI firn was wet during acquisition of the SRTM.

In view of the above, we put the SRTM C- and X-bands into the same vertical datum and performed the co-registration. Although our study area is very close and under similar climatic conditions to that of Willis and others (2012a, b), we found a mean offset of $0.03 \mathrm{~m}$ between the SRTM C- and X-bands which, hence, was neglected.

Apart from the uncertainty linked to the scale of the spatial autocorrelation of the elevation differences, Rolstad and others (2009) also showed that additional systematic 
uncertainties in geodetical determinations arise from changing glacier areas over the $t_{0}-t_{1}$ period (Zemp and others, 2013). To investigate this would have required a new inventory for the year 2012, so instead we calculated the mass budget for seven glaciers, each one belonging to one of the size classes of Figure 4, and assuming linear area change over $t_{0}-t_{1}$ (Table 5). Predictably, the difference in mass budget is greater for the small sized classes than for the larger classes, as a given change in elevation is divided over a smaller area.

Berthier and others (2016) and Nuimura and others (2012) have also performed GPS surveys to calibrate the source DEMs both on- and off-glacier. Their studies have shown that assessing the uncertainty of geodetic mass-balance determinations purely on the basis of statistical analyses might still not be entirely satisfactory, as the off-glacier bedrock and soil have slopes and roughness unrepresentative of the glacier surface (Rolstad and others, 2009). For an exhaustive analysis of the reservations involved in geodetic mass-balance calculations, it can be argued that additional seasonality corrections should also apply (Fischer and others, 2015). In all of these cases, ground truth data, contemporary to the DEM acquisition time, are required, though they are more often than not unavailable.

\section{CONCLUSIONS}

This study presents a new glacier inventory for the year 2000 and a geodetic mass-balance estimate for the Aysén (Chile) and Santa Cruz Province (Argentina) regions between 2000 and 2012.

We used well-established techniques based on Landsat ETM+ band ratios to map 2253 glaciers and $1314 \pm 66$ $\mathrm{km}^{2}$ of glacier area.

DEMs derived from the SRTM (2000) X- and C-bands and the SPOT5 HRS sensor (2012) were used to provide individual average elevation changes for the 2253 inventoried glaciers. The results here represent the first regional assessment of glacier elevation and mass changes for this particular region, (and in general for the Chilean-Argentinean Andes beyond the Patagonian Icefields), where detailed, insitu surveys are scarce or nonexistent.

Precise co-registration of radar (SRTM) and optically derived SPOT DEM elevation grids followed by DEM differencing revealed an area-averaged thinning rate of $0.52 \pm$ $0.35 \mathrm{~m} \mathrm{a}^{-1}$. The corresponding volume change of $-0.71 \pm$ $0.55 \mathrm{~km}^{3} \mathrm{a}^{-1}$ accounted for a geodetic mass budget of $-0.46 \pm 0.37 \mathrm{~m}$ w.e. $\mathrm{a}^{-1}$ for the entire area.

A relatively high variability in individual glacier response and relatively strong correlations between glacier thinning and glacier slope, size and aspect were found. Our investigations further revealed that the greatest lowering rates occur for lake terminating, debris-covered glaciers, where feedbacks occur between glacier surface lowering, calving processes, the low flow rates and gentle slopes of the glacier tongues and the growth of glacial lakes.

While the mean $-0.46 \pm 0.37 \mathrm{~m}$ w.e. $\mathrm{a}^{-1}$ mass balance is nowhere near the strong thinning rates of the closest glaciers outside the investigated area (NPI and SPI), it nevertheless confirms the general tendency of sustained glacier shrinkage in the area as reported in earlier estimates of glacier areal changes. Moreover, this value is close to the global massbalance average.

\section{ACKNOWLEDGEMENTS}

Data presented in this paper may be obtained by contacting the corresponding author. We acknowledge the Agencia Nacional de Promoción Científica y Técnica (grant PICT 2007-0379) and Consejo Nacional de Investigaciones Científicas y Técnicas for funding this study. E. Berthier and the SPIRIT project kindly provided the SPOT5 DEM and the co-registration tool. T. Bolch and P. Rastner acknowledge funding by the European Space Agency (Glaciers_cci project, code 400010177810IAM). We thank Frank Paul and Michael Zemp (University of Zurich) for their comments on the elevation change accuracy assessment. Ricardo Villalba, Alberto Ripalta, Lucas Ruiz, Aldo Perinetti (IANIGLA) and Leo Montenegro (Parque Nacional Perito Moreno) helped with the survey and processing of ground control points. Alberto Vich helped out with the statistical analysis, and Robert Bruce proofread the manuscript for language checking. Special thanks to Michael Bevis from Ohio State University and Bob Smalley from Memphis State University, USA, for providing the necessary GNSS station data. Finally, we thank Graham Cogley, Neil Glasser and two anonymous reviewers for their valuable comments and suggestions, which led to a much improved final manuscript.

\section{REFERENCES}

Abermann J, Kuhn M and Fischer A (2011) Climatic controls of glacier distribution and changes in Austria. Ann. Glaciol., 52 (59), 83-90

Aniya M (1988) Glacier inventory for the Northern Patagonia Icefield, Chile, and variations 1944/45 to 1985/86. Arct. Antarct. Alpine Res., 20(2), 179-187

Aniya M (1999) Recent glacier variations of the Hielos Patagónicos, South America, and their contribution to sea-level change. Arct. Antarct. Alpine Res., 31(2), 165-173 (doi: 10.2307/1552604)

Aniya M (2001) Glacier variations of Hielo Patagónico Norte, Chilean Patagonia, since 1944/45, with special reference to variations between 1995/96 and 1999/2000. Bull. Glacier Res., 18, 55-63

Aniya M, Sato H, Naruse R, Skvarca P and Casassa G (1997) Recent glacier variations in the Southern Patagonia Icefield, South America. Arct. Antarct. Alpine Res., 29(1), 1-12 (doi: 10.1191/ 0959683602hl526rr)

Bakke J and Nesje A (2011) Equilibrium-line-altitude. In Singh V, Singh $\mathrm{P}$ and Haritashya $\mathrm{U}$, eds. Encyclopedia of snow, ice and glaciers. Springer, Dordrecht, The Netherlands, $272 \mathrm{pp}$

Benn DI and Evans DJA (2010) Glaciers and glaciation, 2nd edn. Hodder Education, London

Berthier E, Arnaud Y, Vincent C and Remy F (2006) Biases of SRTM in high-mountain areas: implications for the monitoring of glacier volume changes. Geophys. Res. Lett., 33(8), L08502 (doi: 10.1029/2006GL025862)

Berthier E and 5 others (2007) Remote sensing estimates of glacier mass balances in the Himachal Pradesh (Western Himalaya, India). Remote Sens. Environ., 108, 327-338 (doi: 10.1016/j. rse.2006.11.017)

Berthier E, Schiefer E, Clarke GKC, Menounos B and Remy F (2010) Contribution of Alaskan glaciers to sea-level rise derived from satellite imagery. Nat. Geosci., 3(2), 92-95 (doi: 10.1038/ ngeo737)

Berthier E, Cabot V, Vincent C and Six D (2016) Decadal regionwide and glacier-wide mass balances derived from multi-temporal ASTER satellite digital elevation models. Validation over the Mont-Blanc area. Frontiers Earth Sci., 4(63) (doi: 10.3389/ feart.2016.00063)

Bhattachayra A and 5 others (2016) Overall recession and mass budget of Gangotri Glacier, Garhwal Himalayas, from 1965 to 
2015 using remote sensing data. J. Glaciol., 62(236), 1115-1133 (doi: 10.1017/jog.2016.96)

Bolch T, Buchroithner M, Pieczonka T and Kunert A (2008a) Planimetric and volumetric glacier changes in the Khumbu Himal, Nepal, since 1962 using Corona, Landsat TM and ASTER data. J. Glaciol., 54(187), 592-600 (doi: 10.3189/ 002214308786570782)

Bolch T, Buchroitner $M$, Peters J, Baessler $M$ and Bajracharya S (2008b) Identification of glacier motion and potentially dangerous glacial lakes in the Mt. Everest region/Nepal using spaceborne imagery. Nat. Hazards Earth Syst. Sci., 8, 1329-1340

Bolch T, Menounos B and Wheate RD (2010a) Landsat-based inventory of glaciers in western Canada, 1985-2005. Remote Sens. Environ., 114(1), 127-137 (doi: 10.1016/j.rse.2009.08.015)

Bolch T and 7 others (2010b) A glacier inventory for the western Nyainqentanglha Range and the Nam Co Basin, Tibet, and glacier changes 1976-2009. Cryosphere, 4, 419-433 (doi: 10.5194/tc-4-419-2010)

Bolch T, Pieczonka T and Benn DI (2011) Multi-decadal mass loss of glaciers in the Everest area (Nepal. Himalaya). Cryosphere, 5, 349-358 (doi: 10.5194/tc-5-349-2011)

Bown F, Rivera A, Zenteno P, Bravo C and Cackwell F (2014) First glacier inventory and recent glacier variations of Isla Grande de Tierra del Fuego and adjacent islands in southern Chile. In Kargel JS, Leonard GJ, Bishop MP, Kääb A and Raup B, eds. Global land ice measurements from space. Praxis-Springer, Heidelberg, 661-674

Braithwaite RJ and Raper SCB (2007) Glaciological conditions in seven contrasting regions estimated with the degree-day model. Ann. Glaciol., 46, 297-302

Braithwaite RJ and Raper SCB (2009) Estimating equilibrium-line altitude (ELA) from glacier inventory data. Ann. Glaciol., 50 (53), 127-132

Buttstädt M, Möller M, Iturraspe R and Schneider C (2009) Mass balance evolution of Martial Este Glacier, Tierra del Fuego (Argentina) for the period 1960-2099. Adv. Geosci., 22, 117-124

Carturan L and 10 others (2013) Area and volume loss of the glaciers in the Ortles-Cevedale group (Eastern Italian Alps): controls and imbalance of the remaining glaciers. Cryosphere, 7, 1339_ 1359 (doi: 10.5194/tc-7-1339-2013)

Cogley JG (2009) Geodetic and direct mass-balance measurements: comparison and joint analysis. Ann. Glaciol., 50(50), 96-100 (doi: 10.3189/172756409787769744)

Condom T, Coudrain A, Sicart JE and Théry S (2007) Computation of the space and time evolution of equilibrium-line altitudes on Andean glaciers $\left(10^{\circ} \mathrm{N}-55^{\circ} \mathrm{S}\right)$. Global Planet. Change, 59, 189 202 (doi: 10.1016/j.gloplacha.2006.11.021)

Chen JL, Wilson CR, Tapley BD, Blankenship DD and Ivins ER (2007) Patagonia ice field melting observed by gravity recovery and climate experiment (GRACE). Geophys. Res. Lett., 34, L22501 (doi: 10.1029/2007GL031871)

Davies BJ and Glasser NF (2012) Accelerating shrinkage of Patagonian glaciers from the Little Ice Age ( AD 1870) to 2011. J. Glaciol., 58(212), 1063-1084 (doi: 10.3189/ 2012JoG12J026)

Falaschi D, Bravo C, Masiokas M, Villalba R and Rivera A (2013) First glacier inventory and recent changes in glacier area in the Monte San Lorenzo Region $\left(47^{\circ} \mathrm{S}\right)$, Southern Patagonian Andes, South America. Arct. Antarct. Alpine Res., 45(1), 19-28 (doi: 10.1657/1938-4246-45.1.19)

Fischer M, Huss M and Hoelzle M (2015) Surface elevation and mass changes of all Swiss glaciers 1980-2010. Cryosphere, 9 525-540 (doi: 10.5194/tc-9-525-2015)

Fisher PF and Tate NJ (2006) Causes and consequences of error in digital elevation models. Prog. Phys. Geograph., 30(4), 467-489

Frey $\mathrm{H}$ and Paul $\mathrm{F}$ (2012) On the suitability of the SRTM DEM and ASTER GDEM for the compilation of topographic parameters in glacier inventories. Int. J. Appl. Earth Observ. Geoinfo., 18, 480-490 (doi: 10.1016/j.jag.2011.09.020)
Gardelle J, Berthier E and Arnaud Y (2012) Impact of resolution and radar penetration on glacier elevation changes computed from DEM differencing. J. Glaciol., 58(208), 419-422 (doi: 10.3189/ 2012JoG11J175)

Gardelle J, Berthier E, Arnaud Y and Kääb A (2013) Region-wide glacier mass balances over the Pamir-Karakoram-Himalaya during 1999-2011. Cryosphere, 7, 1263-1286 (doi: 10.5194/ tc-7-1263-2013)

Gardner AS and 15 others (2013) A reconciled estimate of glacier contributions to sea-level rise: 2003 to 2009. Science, 340 (6134), 852-857 (doi: 10.1126/science.1234532)

Garreaud RD (2009) The Andes climate and weather. Adv. Geosci. $7,1-9$

Garreaud R, López P, Minvielle M and Rojas M (2013) Large scale control on the Patagonia climate. J. Clim., 26, 215-230 (doi: 10.1175/JCLI-D-12-001.1)

Giessen RH and Oerlemans J (2013) Climate-model induced differences in the 21 st century global and regional glacier contributions to sea-level rise. Clim. Dynam., 14(11-12), 3283-3300 (doi: 10.1007/s00382-013-1743-7)

Hock R, de Woul M, Radić V and Dyurgerov M (2009) Mountain glaciers and ice caps around Antarctica make a large sea-level rise contribution. Geophys. Res. Lett., 36, L07501 (doi: 10.1029/2008GL037020)

Hoelzle $M$ and 5 others (2007) The application of glacier inventory data for estimating past climate change effects on mountain glaciers: a comparison between the European Alps and the Southern Alps of New Zealand. Global Planet. Change, 56, 69-82

Huss M (2013) Density assumptions for converting geodetic glacier volume change to mass change. Cryosphere, 7, 877-887 (doi: 10.5194/tc-7-877-2013)

Ivins ER and 5 others (2011) On-land ice loss and glacial isostatic adjustment at the Drake Passage: 2003-2009. J. Geophys. Res., 116, B02403 (doi: 10.1029/2010JB007607)

Jaber WA, Floricioiu D, Rott H and Eineder M (2013) Surface elevation changes of glaciers derived from SRTM and TanDEM-X DEM differences. In Proceedings of the 2013 IEEE International Geoscience and Remote Sensing Symposium (IGARSS 2013), Melbourne, Australia, 21-26 July 2013. Institute of Electrical and Electronics Engineers (IEEE), Piscataway, NJ, 1893-1896, ISBN 978-1-4799-1114-1

Jacob T, Wahr J, Pfeffer WT and Swenson S (2012) Recent contributions of glaciers and ice caps to sea level rise. Nature, 482,514 518 (doi: 10.1038/nature10847)

Kääb A, Treichler D, Nuth C and Berthier E (2015) Contending estimates of 2003-2008 glacier mass balance over the PamirKarakoram-Himalaya. Cryosphere, 9, 557-564 (doi: 10.5194/ tc-9-557-2015)

Kienholz C, Hock R and Arendt AA (2013) A new semi-automatic approach for dividing glacier complexes into individual glaciers. J. Glaciol., 59(217), 925-936 (doi: 10.3189/2014JoG13J176)

Koblet T and 6 others (2010) Reanalysis of multi-temporal aerial images of Storglaciaren, Sweden (1959-99) - part 1: determination of length, area, and volume changes. Cryosphere, 4, 333-343 (doi: 10.5194/tc-4-333-2010)

Korona J, Berthier E, Bernard M, Rémy F and Thouvenot E (2009) SPIRIT. SPOT 5 stereoscopic survey of Polar ice: reference images and topographies during the fourth international polar year (2007-2009). ISPRS J. Photogramm. Remote Sens., 64, 204-212 (doi: 10.1016/j.isprsjprs.2008.10.005)

Le Bris R and Paul F (2015) Glacier-specific elevation changes in western Alaska. Ann. Glaciol., 56(70), 184-192 (doi: 10.3189/ 2015AoG70A227)

Lenzano MG (2013) Assesment of ASTER DTM for glaciological applications in Central Andes. Mt. Aconcagua, Argentina. J. Photogramm. Remote Sens. Geoinfo. Process., 3, 197-208

Lüthje M, Pedersen LT, Reeh N and Greuell W (2006) Modelling the evolution of supraglacial lakes on the West Greenland ice-sheet margin. J. Glaciol., 52(179), 608-618 (doi: 10.3189/ 172756506781828386) 
Marzeion B, Jarosch AH and Hofer M (2012) Past and future sealevel change from the surface mass balance of glaciers. Cryosphere, 6, 1295-1322 (doi: 10.5194/tc-6-1295-2012)

Masiokas MH and 12 others (2015) Inventory and recent changes of small glaciers on the northeast margin of the Southern Patagonia Icefield, Argentina. J. Glaciol., 61(227), 511-523 (doi: 10.3189/ 2015JoG14J094)

Möller M and Schneider C (2010) Volume change at Gran Campo Nevado, Patagonia, 1984-2000: a reassessment based on new findings. J. Glaciol., 56(196), 363-365

Nuimura T, Fujita K, Yamaguchi S and Sharma RR (2012) Elevation changes of glaciers revealed by multitemporal digital elevation models calibrated by GPS survey in the Khumbu region, Nepal Himalaya, 1992-2008. J. Glaciol., 58(210), 648-656 (doi: 10.3189/2012JoG11J061)

Nuth C and Kääb A (2011) Co-registration and bias corrections of satellite elevation data sets for quantifying glacier thickness change. Cryosphere, 5, 271-290 (doi: 10.5194/tc5-271-2011)

Paul F (2008) Calculation of glacier elevation changes with SRTM: is there an elevation-dependent bias? J. Glaciol., 54, 945-946 (doi: 10.3189/002214308787779960)

Paul F and Andreassen LM (2009) A new glacier inventory for the Svartisen region, Norway, from Landsat ETM_data: challenges and change assessment. J. Glaciol., 55, 607-619

Paul F and Haeberli W (2008) Spatial variability of glacier elevation changes in the Swiss Alps obtained from two digital elevation models. Geophys. Res. Lett., 35(21), L21502 (doi: 10.1029/ 2008GL034718)

Paul F and Mölg N (2014) Hasty retreat of glaciers in northern Patagonia from 1985 to 2011. J. Glaciol., 60(224), 1033-1043 (doi: 10.3189/2014JoG14J104)

Paul F and 18 others (2013) On the accuracy of glacier outlines derived from remote sensing data. Ann. Glaciol., 54(63), 171182 (doi: 10.3189/2013AoG63A296)

Paul F and 24 others (2015) The glaciers climate change initiative: methods for creating glacier area, elevation change and velocity products. Remote Sens. Environ., 162, 408-426 (doi: 10.1016/j. rse.2013.07.043)

Pfeffer WT and 19 others (2014) The Randolph Glacier Inventory: a globally complete inventory of glaciers. J. Glaciol., 60(221), 537552 (doi: 10.3189/2014JoG13J176)

Pieczonka T and Bolch T (2015) Region-wide glacier mass budgets and area changes for the Central Tien Shan between $\sim 1975$ and 1999 using Hexagon KH-9 imagery. Global Planet. Change, 128, 1-13 (doi: 10.1016/j.gloplacha.2014.11.014)

Pieczonka T, Bolch T and Buchroithner M (2011) Generation and evaluation of multitemporal digital terrain models of the Mt. Everest area from different optical sensors. ISPRS J. Photogramm. Remote Sens., 66, 927-940 (doi: 10.1016/j.isprsjprs.2011.07. 003)

Post A, O'Neel S, Motyka RJ and Streveler G (2011) A complex relationship between calving glaciers and climate. EOS, 97(37), 305306 (doi: 10.1029/2011EO370001)

Quincey DJ and 6 others (2007) Early recognition of glacial lake hazards in the Himalaya using remote sensing datasets. Global Planet. Change, 56, 137-152

Racoviteanu AE, Paul F, Raup B, Khalsa SJS and Armstrong R (2009) Challenges and recommendations in mapping of glacier parameters from space: results of the 2008 Global Land Ice Measurements from Space (GLIMS) workshop, Boulder, Colorado, USA. Ann. Glaciol., 50, 53-69

Radić V and Hock R (2011) Regionally differentiated contribution of mountain glaciers and ice caps to future sea-level rise. Nat. Ceosci., 4, 91-94 (doi: 10.1038/ngeo1052)

Rastner P and 5 others (2012) The first complete inventory of the local glaciers and ice caps on Greenland. Cryosphere, 6, 1483-1495 (doi: 10.5194/tc-6-1483-2012)

Rastner P, Joerg PC, Huss M and Zemp M (2016) Historical analysis and visualization of the retreat of Findelengletscher, Switzerland,
1859-2010. Global Planet. Change, 145, 67-77 (doi: 10.1016/j. gloplacha.2016.07.005)

Rignot E, Echelmeyer K and Krabill W (2001) Penetration depth of interferometric synthetic-aperture radar signals in snow and ice. Geophys. Res. Lett., 28(18), 3501-3504 (doi: 10.1029/2000GL012484)

Rignot E, Rivera A and Casassa G (2003) Contribution of the Patagonian icefields of South America to sea level rise. Science, 302(5644), 434-437

Rivera A, Casassa G, Bamber J and Kääb A (2005) Ice-elevation changes of Glaciar Chico, southern Patagonia, using ASTER DEMs, aerial photographs and GPS data. J. Glaciol., 51(172), 105-112

Rivera A, Benham T, Casassa G, Bamber J and Dowdeswell JA (2007) Ice elevation and areal changes of glaciers from the Northern Patagonia Icefield, Chile. Global Planet. Change, 59, 126-137 (doi: 10.1016/j.gloplacha.2006.11.037)

Rivera A, Corripio J, Bravo C and Cisternas S (2012) Glaciar Jorge Montt (Chilean Patagonia) dynamics derived from photos obtained by fixed cameras and satellite image feature tracking. Ann. Glaciol., 53(60), 147-155 (doi: 10.3189/2012AoG60A152)

Rolstad C, Haug T and Denby B (2009) Spatially integrated geodetic glacier mass balance and its uncertainty based on geostatistical analysis: application to the western Svartisen ice cap, Norway. J. Glaciol., 55, 666-680

Ruiz L, Berthier E, Viale M, Pitte P and Masiokas M (2016) Recent geodetic mass balance of Monte Tronador glaciers, North Patagonian Andes. Cryosphere Discuss. (doi: 10.5194/tc-2016-170)

Sagredo EA and Lowell TV (2012) Climatology of Andean glaciers: a framework to understand glacier response to climate change. Global Planet. Change, 86-87, 101-109 (doi: 10.1016/j. gloplacha.2012.02.010)

Sakakibara D and Sugiyama S (2014) Ice-front variations and speed changes of calving glaciers in the Southern Patagonia Icefield. J. Geophys. Res. F: Earth Surf., 119, 2541-2554 (doi: 10.1002/ 2014JF003148)

Sapiano JJ, Harrison WD and Echelmeyer KA (1998) Elevation, volume and terminus changes of nine glaciers in North America. J. Glaciol., 44, 119-135

Schaefer M, Machguth H, Falvey M, Casassa G and Rignot E (2015) Quantifying mass balance processes on the Southern Patagonia Icefield. Cryosphere, 9, 25-35 (doi: 10.5194/tc-9-25-2015)

Schneider C, Schnirch M, Acuña C, Casassa G and Kilian R (2007) Glacier inventory of the Gran Campo Nevado Ice Cap in the Southern Andes and glacier changes observed during recent decades. Global Planet. Change, 59, 87-100

Sexton JO, Bax T, Siqueira P, Swenson JJ and Hensley S (2009) A comparison of lidar, radar, and field measurements of canopy height in pine and hardwood forests of southeastern North America. Forest Ecol. Manag., 257(3), 1136-1147 (doi: 10.1016/j.foreco.2008.11.022)

Strelin JA and Iturraspe R (2007) Recent evolution and mass balance of Cordón Martial glaciers. Cordillera Fueguina Oriental. Global Planet. Change, 59(1-4), 17-26

Villalba R and 9 others (2003) Large-scale temperature changes across the Southern Andes: 20th-century variations in the context of the past 400 years. Clim. Change, 59, 177-232 (doi: 10.1023/A:1024452701153)

Warren CR and Sugden DE (1993) The Patagonian icefields: a glaciological review. Arct. Antarct. Alpine Res., 25(4), 316-331

WGMS (2013) Glacier mass balance bulletin no. 12 (2010-2011). In Zemp $M$ and 6 others, eds. ICSU(WDS)/IUGG(IACS)/UNEP/ UNESCOMMO. World Glacier Monitoring Service, Zurich, Switzerland (doi: 10.5904/wgms-fog-2013-11)

Willatt RC, Giles KA, Laxon SW and Worby A (2010) Field investigations of Ku-band radar penetration into snow cover on Antarctic Sea Ice. IEEE Trans. Geosci. Remote Sens., 48(1), 365-372 (doi: 10.1109/TGRS.2009.2028237)

Willis MJ, Melkonian AK, Pritchard ME and Ramage JM (2012a) Ice loss rates at the Northern Patagonian Icefield derived using a 
decade of satellite remote sensing. Remote Sens. Environ., 117, 184-198 (doi: 10.1016/j.rse.2011.09.017)

Willis MJ, Melkonian AK, Pritchard ME and Rivera A (2012b) Ice loss from the Southern Patagonian Ice Field, South America, between 2000 and 2012. Geophys. Res. Lett., 39, L17501 (doi: 10.1029/ 2012GL053136)

Wilson R, Carrión D and Rivera A (2016) Detailed dynamic, geometric and supraglacial moraine data for Glaciar Pio XI, the only surge-type glacier of the Southern Patagonia Icefield. Ann. Glaciol., 57(73), 119-130 (doi: 10.1017/aog.2016.32)
Yde JC and Paasche Ø (2010) Reconstructing climate change: not all glaciers suitable. Eos Trans. AGU, 91(21), 189-190 (doi: 10.1029/2010EO210001)

Zemp M and 16 others (2013) Reanalysing glacier mass balance measurement series. Cryosphere, 7, 1227-1245 (doi: 10.5194/ tc-7-1227-2013)

Zemp M and 38 others (2015) Historically unprecedented global glacier decline in the early 21st Century. J. Glaciol., 61(228), 745-762 (doi: 10.3189/2015JoG15J017)

MS received 12 July 2016 and accepted in revised form 30 November 2016; first published online 28 December 2016 